IFN Working Paper No. 1265, 2019

\title{
The Refugee Crisis and the Reinvigoration of the Nation State: Does the European Union Have a Common Asylum Policy?
}

Magnus Henrekson, Özge Öner and Tino Sanandaji 


\title{
The Refugee Crisis and the Reinvigoration of the Nation State: Does the European Union Have a Common Asylum Policy?
}

\author{
Magnus Henrekson*, Özge Öner ${ }^{\dagger}$, and Tino Sanandaji ${ }^{\ddagger}$
}

August 18, 2019

\begin{abstract}
The European Union officially proclaims to have a common asylum policy. However, the common treaties leave a great deal of discretion to the individual member countries, which allow them to regulate refugee migration while still upholding international treaties. Member countries have authority over border controls, the processing of asylum applications as well as economic benefits provided to refugees. We show that the differences in refugee flows are so extensive and systematic that the existence of a common EU asylum policy is debatable. The commitments made by the member countries are largely voluntary, and asylum policy is mainly determined at the national level. The discrepancies between the member countries strongly signal that the European Union may not be an optimal region for a common asylum policy. An asylum policy should instead be determined at the national level concordant with the regional and local level, where integration measures are implemented in practice. Meanwhile, the European Union can play an important role through refugee aid to afflicted countries, treaties with third countries, rescue actions in the Mediterranean and control of the external EU borders.
\end{abstract}

Keywords: Asylum policy; Asylum seekers; European Union; Migration policy; Refugee crisis; Schengen Agreement.

JEL Codes: F22, F53, H37, J61, K37.

\footnotetext{
This is a forthcoming chapter in The European Union and the Return of the Nation State, edited by Antonina Bakardjieva Engelbrekt, Anna Michalski, Karin Leijon, and Lars Oxelheim. Cham, CH: Palgrave Macmillan.

${ }^{*}$ Research Institute of Industrial Economics (IFN), P.O. Box 55665, SE-102 15 Stockholm, Sweden. Email: magnus.henrekson@ifn.se.

${ }^{\dagger}$ University of Cambridge, Department of Land Economy, Silver Street 19, CB3 9EP, Cambridge, UK, and Research Institute of Industrial Economics (IFN), P.O. Box 55665, SE-102 15 Stockholm, Sweden. Email: oo263@cam.ac.uk.

$\$$ Institute for Economic and Business History Research (EHFF), Stockholm School of Economics, P.O. Box 6501, SE-113 83 Stockholm, Sweden. Email: tino.sanandaji@hhs.se.

Acknowledgement: Magnus Henrekson and Özge Öner gratefully acknowledge financial support from Jan Wallanders och Tom Hedelius stiftelse.
} 


\section{Introduction}

One of the fundamental debates in the European Union (EU) concerns the appropriate degree of federalism for the Union, and the ensuing question which policies should be conducted at the EU or the national level for the 28 member states. A core component of the EU project is the free movement of workers and students across member states. This freedom is supported by a majority in all member countries (European Commission 2018a). By contrast, a far more contentious issue is the ambition of the EU to lay down and enforce a common asylum policy.

The representatives of the EU as well as the member states officially claim that the Union does have a common asylum policy. However, existing agreements give considerable room for maneuver to the individual member states. This discretion enables them to individually regulate the intake of refugees and still comply with international agreements.

In this context it is important to clearly distinguish between different types of migration. The factors that determine migration from within Europe and high-skilled migration from non-EU countries differ from factors determining migration by refugees and asylum seekers. In this chapter we focus on refugees and asylum seekers from outside of Europe.

The refugee crisis in the fall of 2015 revealed an inherent weakness of the EU as a federal project, while at the same time reemphasizing the continued dominance of sovereign European nation states. The crisis also showed the ineffectiveness of a common migration policy for all EU member countries coordinated from Brussels, as the EU failed to deal with the sharply increased flow of asylum seekers.

Instead, several individual member states began to introduce border controls by referring to the possibility of exemption from the Schengen Agreement if countries experience a serious threat to public order and internal security. The member states are given considerable scope to decide whether this is the case, and thus whether an exemption may be renewed. Not least Sweden, the country that has received by the largest number of refugees per capita, has made use of this opportunity. Border control to other Schengen countries was introduced in November 2015 and following several extensions such control was still effective in August 2018. 
This chapter shows that the cross-country differences in the reception of refugees are so large and systematic that it is not meaningful to speak of a common EU asylum policy. The asylum policy is governed by a number of policy tools and as the extent to which countries coordinate their asylum policies at the EU level is largely voluntary, it is mainly determined by domestic politics. When there are large refugee flows and tensions between members, the tendency to stick to a domestic political agenda is amplified. Even though there is a de jure asylum system equally applicable to all EU countries, we argue that no such system exists in practice. Nation states continue to control border enforcement, asylum application agencies, and welfare state policies that determine the degree of generosity towards refugee migrants, which means that the de facto commitments of EU member countries based on existing agreements are largely symbolic. After having shown that the EU lacks a common asylum policy, we will discuss whether policies pertaining to refugees are most appropriately determined at the national level, or whether the role of the EU ought to be strengthened.

In the following section, we make a brief presentation of the core principles underlying EU cooperation with respect to migration. In section three, we discuss the public opinion vis-à-vis asylum policy and the skepticism against the EU project more generally that has been fueled by the recent refugee crisis. In section four, we present the international agreements pertaining to the treatment of refugees as well as the specific EU asylum legislation. This is followed by section five which deals with governance problems that arise as a result of the fact that responsibilities for decisions and integration measures involve a large number of actors on different interconnected levels. In section six, we analyze the large cross-member differences with respect to refugee intake and labor market integration. This is followed by a section where we discuss the conflict between the federal and the national governance level and the risks for the EU project at large if the EU forces its member countries to harmonize their respective refugee policies to an extent that lacks public support. In the concluding section we offer our policy recommendations on how the EU can identify the optimal level of federalism versus nation state sovereignty in immigration policy.

\section{A Common EU Asylum Policy in Theory and Practice}

Although there is no formal definition of the EU as a federal state, the Union has gradually developed some basic federal features (Kelemen 2007). The EU has been endowed with supranational power in a number of policy areas, notably with respect to the monetary union and its 19 member states (Andersson 2019). The purview of the Union's power is increasingly 
extending into the core of traditional national responsibilities-such as internal security, notably through visa rules and immigration.

The most important aspect that differentiates the EU from federal states-such as the United States, Belgium, and Australia - is the fact that the Union does not have the power of enforcement by its own police, security, and defense forces. Such power belongs to the individual member states, and the Union relies on its member states to enforce the regulations and policies made at the Union level. In this respect, the EU is much more decentralized than a typical federal state.

Free movement of labor and capital is an essential component of the foundation of the EU. The emphasis on free movement is linked to the ideal to create European identity and integrate the European nations. One important development in order to create a European Union with open borders between the member states is the Schengen Agreement. The agreement was signed in 1985 by five of the then ten member states (France, West Germany, the Netherlands, Belgium, and Luxembourg). The agreement entailed the complete elimination of internal border controls between the signatories and the establishment of a common visa policy. The fact that the agreement was initially signed only by five countries also meant that the borders of the Schengen Area have undergone a sizable expansion as the number of member states increased. At the beginning of 2019 the Schengen Area consisted of 26 European countries: all EU countries except the UK, Ireland, Cyprus, Bulgaria, Romania, and Croatia, plus Norway, Iceland, Switzerland, and Liechtenstein. In total it encompasses a population of over 400 million people and an area of 4.3 million square kilometers.

However, the enlargement of the EU through the addition of eleven former Eastern Bloc countries resulted in sharply increased differences in average incomes as well as in the overall quality of institutions of the member states (Elert et al. 2017, 2019; Dilli et al. 2018). In the absence of borders and strict rules concerning immigration across the member states, these large cross-member differences induced large-scale labor migration from poorer to richer EUcountries.

Terms such as refugees, migrants, and asylum seekers are sometimes used interchangeably, but it is useful to be clear about the distinctions in order to avoid confusion. Not all asylum seekers will be granted asylum, and some choose to withdraw their application. At the same time, many 
immigrants do not obtain legal residence permit as asylum seekers, but instead through family reunification, labor migration or as students. It is also not unusual for asylum seekers, who are denied asylum, to become immigrants through these channels - notably as labor migrants or as students. Additionally, some asylum seekers, who are initially denied asylum, eventually obtain asylum after appealing in court or after filing a new application. Even for those who are granted asylum as refugees, there is usually a lag of one to two years from the point of applying for asylum until the person becomes registered as an immigrant.

The Schengen Agreement lays down common rules regarding the treatment of asylum seekers. After the acute refugee crisis in the fall of 2015, the public discourse shifted in many European countries-international solidarity was downplayed, while issues of national identity were given increased weight. This tendency was strengthened when the EU failed to agree on and implement efficient measures to deal with the crisis. The Schengen Agreement allows individual members to reinstate internal border controls in case of an emergent "public policy or national security" reason. If the emergency continues, the controls can be extended. These exceptions are intended to be temporary and exceptional, but this possibility has been used broadly by several countries which have continually renewed and extended the internal border controls. In August 2019, six Schengen countries still had such controls in force. ${ }^{1}$

\section{Public Opinion and Euroscepticism}

The political importance of migration policy has grown both at the European level and at the level of individual member states. At least to some extent, this is also true for the issue of free cross-country mobility within the Union. Surveys indicate that voters overall see both a role for the EU and for individual member states in migration policy. In the spring 2018 Eurobarometer, 68 percent of Europeans supported a common European policy on migration. Regarding irregular migration, for example during a refugee crisis, 38 percent of respondents reported that additional measures should be taken "preferably at an EU level", and an additional 23 percent reported that additional measures should be at both EU and member state levels (European Commission 2018b). However, the nation state is seen as having the superior role by most respondents. A 2017 Pew Survey showed that the majority of citizens in all surveyed European countries (nine countries were included in the study) believed that national government rather than the EU should make decisions about migration. The median share of respondents who were of the opinion that decisions regarding the migration of non-EU citizens should be made

\footnotetext{
${ }^{1}$ Norway, Sweden, Denmark, Germany, Austria, and France; see European Commission (2019a).
} 
in Brussels was 23 percent, while 74 percent said such decisions should be taken by the respective national governments (Stokes et al. 2017).

While the gradually increasing federalization of the EU has been a voluntary process, strong Eurosceptic sentiments have recently arisen among many member states, particularly related to the migration crisis. Although Eurosceptic views came under the spotlight following the Brexit referendum, its historical roots are much older. This critique is found both on the left and the right side of the political spectrum in virtually all member states.

The ultimate example of EU skepticism is the British decision to leave the Union following a referendum in 2016. But the United Kingdom is not alone. According to Eurobarometer the share of respondents who express trust in the EU and its institutions has declined strongly since its peak of 57 percent in 2007, and while recovering somewhat in recent years this share has since then remained below 50 percent (European Commission 2018a). Country differences are large: trust is greatest in Lithuania, Portugal, and Denmark and lowest in Greece, the United Kingdom, and France. Issues the EU is most criticized for include the Common Agricultural Policy, onerously regulated labor markets, and the deflationary bias of the European Central Bank. However, after 2015 these issues are eclipsed by the EU's management of the refugee inflow.

Sweden is an extreme case by having accepted more refugees per capita than any other EU country. However, there is no strong political force pushing for a Swedish exit from the EU. While demands for a more restrictive immigration policy have grown considerably, support for the Union has also increased. Despite the failure of the common EU migration policy, people in Sweden seem able to appreciate the fact that the economic integration achieved through EU membership impacts positively on growth and job creation and thus on the potential for successful integration of immigrants. This view is confirmed by results from SVT's (the Swedish public service television company) poll of 12,000 voters on election day (September 9, 2018), where numerous questions were asked (SVT 2018). Regarding the proposal to "accept fewer refugees into Sweden", 26 percent said that this was a bad proposal, 52 percent that it was a good proposal, while the remaining 22 percent expressed no opinion. Thus, two thirds of those who expressed an opinion wanted Sweden to accept fewer refugees. At the same time, 69 percent said that it was a bad idea to for Sweden to leave the EU, and in contrast a mere 15 percent thought it was a good idea. It is obvious that there is strong support in the Swedish 
electorate for continued EU membership while at the same time many voters favor a more restrictive asylum policy.

Immigration is by far the issue that is most contentious and thus has the greatest centrifugal potential. According to a press release by the European Commission that summarizes the findings of the spring 2018 Standard Eurobarometer, European citizens consider immigration as the number one challenge for the EU to tackle, followed by terrorism (European Commission 2018a). While 65 percent express positive feelings towards migration of people from other EU member states, only 41 percent express positive feelings towards immigration from outside the EU. It should moreover be noted that this question on sentiments towards migration is fairly general, it does not specifically address refugee migration.

An analogy can be made between the challenges of a common asylum policy and the problems of the euro zone. The discussion among economists about the euro has focused on the question whether Europe is an optimal currency area composed of regions symmetrically affected by external disturbances (Mundell 1961; Andersson 2019). Many analysts maintain that the economic structure of the countries and regions that have a common currency is not sufficiently similar for this arrangement to be appropriate. The imposition of a common asylum policy may be even more inappropriate; not only economic differences but also differences in religion, culture, social norms, and levels of education speak against policy harmonization in this area.

More importantly, many of the problems that arise and need to be resolved by a country are pushed downward from the national to the regional and local/municipal level. These lower levels of governance often lack the economic resources and institutions required to successfully manage lengthy and complex integration processes.

This being said, one should not forget that the EU has achieved some results when it comes to the common migration policy, notably through the establishment of the European Border and Coast Guard Agency (Frontex) and reaching an agreement to guard the EU border with Turkey.

\section{Asylum Law in the EU}

In order to understand why there are such large differences in refugee flows across member states despite that these states are subject to the same (or a similar) legal framework, we will 
now summarize the legal roots of the Asylum Law in the EU and review the legal efforts made by the EU following the 2015 surge in refugee immigration.

The Geneva Convention from 1951 is the first international treaty regulating the right of asylum. The Convention broadly defines a refugee as someone who (Cherubini 2014, p. 9):

As a result of events occurring before 1 January 1951 and owing to a well-founded fear of being persecuted for reasons of race, religion, nationality, membership of a particular social group or political opinion, is outside the country of his nationality and is unable, or owing to such fear, is unwilling to avail himself of the protection of that country; or who, not having a nationality and being outside the country of his former habitual residence as a result of such events, is unable or, owing to such fear, is unwilling to return to it.

The above definition of a refugee, or universal acknowledgement of an individual's status as a refugee, does not mean that refugee status is conferred in practice. This point is particularly important for the fact that determining someone's refugee status, in theory, is not sufficient to determine the right of asylum. Countries receiving refugees have considerable leeway when it comes to the methods and criteria for determining refugee status, which in turn influences whether a person will be granted asylum (Cherubini 2014). Despite the extreme variation in refugee flows to the countries that recognize and abide by the Geneva Convention, this point is often ignored in the public discourse.

The legal criteria that need to be fulfilled for an individual to be defined as a refugee have changed considerably over the years. Since the Geneva Convention was instituted in response to the post-World War II population movements within Europe, it was designed to apply to the individuals that were affected by the events that took place prior to 1951 , and only within Europe. However, the amendment to the Convention in the Protocol Relating to the Status of Refugees, which was ratified in 1967, removed these restrictions. This removal made the Convention applicable at a universal scale. Today only a few states still maintain the geographical restriction. Among those an interesting case is Turkey, which implies that the country has the right to pass asylum seekers and refugees on to other countries. ${ }^{2}$

The Refugee Convention's definition of a refugee can be broken down into a number of elements, which pertain to potential reasons for seeking asylum (Lenzerini 2009). Two key elements are a well-founded fear of persecution and being unable to (or unwilling to) return to

\footnotetext{
${ }^{2}$ Removing the geographical restriction has been imposed as one of the requirements on Turkey in its EU membership accession process (Edsbäcker 2011).
} 
the country of citizenship (or residence). Since fear is subjective, the definition of an individual requesting recognition as a refugee should follow the same subjective line of practice according to the UN refugee agency UNHCR. However, the argument has been made in the legal literature that the notion of "well-founded" suggests that an objective measure, i.e., a measure that does not make room for the alleged state of mind of the individual, should be used to determine the refugee status (Cherubini 2014, p. 13). Obviously, such an objective measure would be ideal, but unfortunately, there exists no unequivocal way of identifying a foolproof practice to arrive at such a measure. Nevertheless, decisions will be taken by national courts and agencies, but there will continue to be room for substantial variation in how the law is interpreted over time and across countries.

Despite the fact that human rights violations are highly relevant when judging whether an individual should be granted refugee status, this does not mean that every human rights violation automatically suffices to grant that person refugee status. The breech needs to be sufficiently severe to be characterized as persecution (Lenzerini 2009, p. 247). The Refugee Convention broadly restricts the reasons that justify recognition of an individual as a refugee to the following five reasons: persecution because of (i) race, (ii) religion, (iii) nationality, (iv) membership of a social group, or (v) political opinions.

As clearly defined as these reasons may seem, there is considerable room for debate whether an individual satisfies the requirements to be recognized as a refugee, or how these five reasons should be interpreted. For example, the Convention initially does not address persecution due to sexual orientation (Wessels 2011). However, "membership in a social group" is sometimes interpreted to cover homosexuality when this is adduced by individuals coming from countries that criminalize homosexuality and/or have sodomy laws (McGhee 2001). However, there are still a number of cases where an individual coming from countries where homosexuality is illegal is not granted refugee status. The reasoning is that even if the country may deem homosexuality illegal, the requirement remains that the person claiming to be persecuted because of his or her sexual orientation is able to prove a well-founded fear of this persecution. ${ }^{3}$

\footnotetext{
${ }^{3}$ One such example is $F$. v. the United Kingdom. An applicant who entered the UK illegally in 2001 claimed asylum on the basis that he feared persecution as a homosexual in Iran where homosexuality is illegal. The UK Adjudicator rejected the applicant's appeal after examining the extent of risk to homosexuals in Iran. The verdict relied on expert opinion that stated that "homosexuality is a common phenomenon in Iran and is tolerated as long as it does not disturb public order and remains in private." The verdict was upheld in the European Court of Human Rights (F. v. United Kingdom 2004, p. 11), which concluded that "the materials examined by the
} 
Individual assessment, therefore, is important in deciding the refugee status and in many cases the claims are considered insufficient. Against this, UNHCR (2002) maintains that

...during a mass exodus such as occurred from Kosovo or Africa's Great Lakes, it may not be possible to carry out individual screening. In such circumstances, particularly when civilians are fleeing for similar reasons, it may be appropriate to declare 'group' determination of refugee status, whereby each civilian is considered as a refugee, prima facie - in other words, in the absence of evidence to the contrary.

The criteria applied by the EU legal framework for the recognition of an individual as a refugee adhere closely to the conditions stated under the Geneva Convention. Since 1999, the EU has been striving to create a Common European Asylum System (CEAS) and to improve the related legal framework. Between 1999 and 2005, several legislative measures harmonizing common minimum standards for awarding asylum were adopted. Moreover, the European Refugee Fund was established to facilitate the reception of asylum seekers and refugees, which was a means to pave the way for a common asylum policy and the creation of a federal asylum system.

In 2001, the EU adopted the directive on temporary protection in the event of a mass influx of displaced persons, the aim of which is to ascertain that all member countries harmonize their actions in such situations. The applicability of the EU Directive on the right to family reunification has also been extended to refugees. The current EU Qualification Directive of 2011 is intended to (European Commission 2018b):

- Clarify the grounds for granting and withdrawing international protection.

- Regulate exclusion and cessation grounds.

- Improve the access of beneficiaries of international protection to rights and integration measures; better take into account the specific practical difficulties faced by beneficiaries of international protection.

- Ensure that the best interest of the child and other gender-related aspects are taken into account in the assessment of asylum applications, as well as in the implementation of the rules on the content of international protection.

In order to further strengthen and harmonize CEAS rules, the Commission submitted a draft proposal for a new Qualification Regulation in July 2016 that covers three additional essential features (European Commission 2016; italics added):

- Ensuring that protection is granted only for as long as the grounds for persecution or serious harm persist without affecting the refugee's integration prospects.

- Addressing secondary movements of beneficiaries of international protection.

- Further harmonizing the rights of beneficiaries of international protection.

domestic authorities and submitted by the applicant do not disclose a situation of active prosecution by the authorities of adults involved in consensual and private homosexual relationships." 
It is fair to say that during the escalated immigration pressure experienced by the EU in the last few years, considerations of the best interest of accompanying children and other gender-related aspects were seldom applicable as the majority of the refugees that arrived to the EU across the Mediterranean were men, ${ }^{4}$ and false statements related to the age of the applicant were common. $^{5}$

The EU's official site on Common European Asylum System (CEAS) states:

Asylum must not be a lottery. EU Member States have a shared responsibility to welcome asylum seekers in a dignified manner, ensuring they are treated fairly and that their case is examined to uniform standards so that, no matter where an applicant applies, the outcome will be similar. ${ }^{6}$

The Dublin Regulation (European Parliament and the Council of the EU 2013) determines the EU member state responsible for examining an application for asylum seekers seeking international protection under the Geneva Convention and the EU Qualification Directive from 2011. The Dublin Regulation applies to all member countries except Denmark. In July 2017, the European Court of Justice declared that the Dublin Regulation still stands, giving EU member states the right to deport migrants to the first country of entry to the EU.

Although all member states ostensibly follow the Geneva Convention and the same EU directives for asylum migration, a shared responsibility and a unified legal treatment are far from the reality of the EU today. The legal wiggle room at the national level in identifying what constitutes a refugee, the capacity of countries to control their own borders, thereby making it more difficult for refugees to enter and apply for asylum, and national discretion regarding the economic incentives facing refugees implies that the asylum policy is de facto determined at the national level. Apparently, most EU member countries prefer this state of affairs.

\section{The Tensions Related to Multi-Level Governance}

Multi-level governance is a concept developed in the early 1990s in political science and public administration studies of European integration (Hooghe and Marks 2001). Many governance problems emanate from the fact that the mandate to command and control is both hierarchically structured and split up across different levels of aggregation: the federal (EU), national, regional, and municipal levels. However, decisions taken at the various levels often interact in

\footnotetext{
${ }^{4}$ See UNHCR (2019).

${ }^{5}$ For example, for Sweden, see Swedish National Forensic Medicine Agency (2018). For Denmark, see Jyllands-Posten's report on Department of Forensic Medicine's investigation (Johansen 2016).

${ }^{6}$ See European Commission (2019b).
} 
complex ways that are not strictly hierarchical. Migration policy and how immigration and integration can be handled in a system of nation states is an archetypical example. How the different levels and their respective competencies best be coordinated has not been laid down at the EU level despite that the EU is supposed to have a common migration policy. Instead, each member state is expected to resolve this complex issue in its own way. Because of this lack of strategy, the recent refugee crisis has given rise to formidable governance challenges in the member states.

An OECD report following the refugee crisis specifically addressed the challenges emanating from variation in multi-level governance across the member states (OECD 2018). After conducting surveys across different levels of government of the member states, they identify a great degree of variation in the way refugee placement and integration policies are implemented. Without going into detail country by country, we list here some of the major concerns related to the multi-level governance in the EU regarding the recent refugee crisis.

First, the OECD study reports that 80 percent of the 72 respondent cities all over Europe state that "there is a lack of co-ordination between different levels of government regarding migrant integration." Two thirds of the respondents identify that this problem is particularly severe with respect to the asylum and refugee population. The overwhelming majority of the respondent cities argued that there exists a large information gap. The report puts forward "institutional mapping" as a potential tool to clarify which governance level is responsible for which public service provision and has the power to implement integration policies. However, such unified mapping is not practicable as the power of local governments as well as their responsibilities regarding which public services they should provide differ greatly across member states.

Related to local governance of migrants and refugees, a number of objectives are identified in the report. These are (i) matching migrant skills with economic job opportunities, (ii) securing access to adequate housing, (iii) providing social welfare measures aligned with migrant inclusion, and (iv) providing educational opportunities that counteract segregation and offer equitable paths to professional growth. The practical implementation of these objectives is far from unproblematic. At times different objectives are in conflict with each other; this problem is particularly severe in some member states due to the massive and unprecedented scale of immigration. In this regard, Sweden can serve as a salient example of conflicting objectives concerning the matching of migrant skills with economic job opportunities and providing 
access to adequate housing. In Sweden, the problem is particularly severe as there is a strongly negative relationship between housing availability and job opportunities at both the local and regional level. Municipalities in economic decline have greater housing availability, but in these municipalities job opportunities are scarce, and unemployment is high. In practice, the national government has prioritized the provision of "a roof over their head", while the objective of matching refugees to job opportunities has been largely disregarded. A significant share of the refugees has been placed in rural municipalities, and this tendency was intensified in the $2010 \mathrm{~s}$ when the flow of asylum seekers increased sharply (Wennström and Öner 2018).

Towards the end of the 2010s, this is clearly a serious impediment to successful integration. This problem can be expected to grow in the medium term as a result of the high rate of asylums granted in the 2006-2017 period, which amounted to approximately five percent of total population in that period. The annual inflow of immigrants in the years to come is likely to remain at that level as a result of the immigration in the form of family reunification that will ensue (Swedish Migration Agency 2018).

Funding is another important matter related to multi-level governance. A sharp increase in the influx of migrants and asylum seekers financially overburdens the system of local service provision. The Swedish example shows that municipalities with greater economic problems tend to opt for accepting a greater number of refugees, either in the hope that they may recover these costs in the long run when the immigrants become self-reliant taxpayers, or thanks to the transfers they receive from the national government.

There is little evidence that those immigrants that were placed in municipalities with a declining native population manage to become self-reliant remain in that municipality. On the contrary, immigrants with good labor market prospects sort themselves into larger labor markets with better opportunities for finding a job (Faggian and Öner 2018). Looking at the EU as a whole, the short-run financial support municipalities get from the national government for receiving refugees varies substantially in duration and size across member states. An obvious alternative would be supranational funding provided by the EU to the member states that assume a disproportionate share of the burden. However, there is no empirical evidence suggesting that EU funds directly target migration-related activities at the municipal level (OECD 2018, p. 100). 


\section{Worlds Apart: Variation in Refugee Flows in the European Union}

The EU has harmonized many policy areas and has long been working toward a common European migration policy. In the political rhetoric, both the European Commission and many national governments often refer to what is described as a comprehensive migration policy common to all member states. While the EU plays an important role with respect to the Dublin Regulation and the external border control, asylum policy is mainly determined at the national level. The $28 \mathrm{EU}$ member states differ greatly in terms of migration rates, immigrant outcomes, and asylum policy. These differences in part reflect varying rates of economic development between Southern, Eastern, and Northern Europe. However, there are also large differences when comparing wealthy member states. Some wealthy EU countries, such as Sweden and Germany, have accepted many refugees, whereas other wealthy EU countries, such as the United Kingdom and Ireland, have taken relatively few.

Eurostat, the statistical agency of the EU, compiles high-quality data on immigration in general and refugee migration in particular. Eurostat (2018) defines immigration as establishing one's chief residence in an EU member state for a period of at least twelve months. Net migration is defined as the difference between the number of immigrants (persons receiving asylum or residence permit) and the number of emigrants who leave the country. Eurostat collects and publishes data on asylum seekers for most of the EU since 1985 and provides comprehensive data for almost all member states since 1990. Eurostat also publishes data on the employment rates of migrants of varying backgrounds. Here we report statistics on non-European immigrants. It should be noted that this is not synonymous to asylum seekers, since many immigrants from outside Europe are not refugees. Nevertheless, the employment outcomes for non-European immigrants illustrate the point that there is great variation among EU countries in their ability to absorb non-European immigrants in the national labor market.

Typically, the share of approved asylum applications ranges from approximately two to 62 percent, but the share varies substantially between countries and over time, and it also depends on which country the asylum seekers come from. During the 2010s the share of granted asylums has been higher than in the past. This is partly explained by the fact that more asylum seekers were from Syria or unaccompanied minors. These categories were granted asylum to a higher degree. 
The reasons for this variation are complex and driven by many factors. As expected, periods of conflict - such as the wars in the former Yugoslavia, Iraq, and Syria—give rise to greater flows of refugees to Europe. The member countries also differ with respect to pull factors that attract immigrants: geography, welfare rights, ease of being granted family reunification, the threshold for being granted status as a refugee, and the willingness to welcome refugees signaled by the country. This leads to stronger inflows of refugees to some countries and cross-country differences in the proportion of approved asylum applications.

Since all EU countries have signed international treaties that oblige them to grant refugees protection under certain conditions, a member state does not fully control the number of refugees it will have to take. The right of being granted refugee status only applies to those asylum seekers that make it into the territory of EU member states. In practice, EU member states regulate refugee inflows through border control that make it difficult for asylum seekers to enter any EU country in the first place (Sanandaji 2017). Thus, although the member states have signed similar international treaties, they may choose to interpret the letter and, even more importantly, the spirit of the law differently. Although international refugee treaties grant asylum seekers certain rights, individual countries still have the right to regulate the inflow of refugees. Perhaps most importantly, the right of asylum only applies to those who make it to the country in the first place and does not require countries to grant immigrants entry visas.

In addition, member states can make it less attractive to apply for asylum by applying more austere economic policies toward refugees such as high thresholds to qualify for financial assistance and social benefits, by only granting temporary asylum, limiting family reunification, and other measures that are within the letter of the law. This policy stance is viewed by many voters in various member states as ungenerous and against the perceived moral right of asylum. The degree of generosity is therefore a contested political issue that varies depending on the political preferences of the electorate and the ideology of the political parties in power.

Those who manage to cross the border into an EU country have the right to apply for asylum, but the country in question has substantial discretion in assessing whether the applicant's need of protection is sufficiently great to warrant asylum. Thus, the large cross-country variation in the rate at which asylums applications are approved is no proof that countries with low approval rates violate international agreements. Instead, it is the result of the great scope for differing interpretations that these agreements allow for. Cross-national differences can also be 
magnified by economic and geographic factors, and the fact that refugee policies vary over time within countries is a further indication that the observed cross-country differences are largely explained by variation in national policies.

Thus, while the refugee inflow is not a discretionary choice, countries have a wide room to maneuver within the framework of international treaties. Differences in asylum policy among EU countries are staggering and make clear that de facto there is no common EU policy. Figure 1 shows the number of persons applying for asylum in the EU countries per thousand inhabitants between 2006 and 2017. In addition to the $28 \mathrm{EU}$ member states, we also include Norway and Switzerland. Countries are ranked according to the number of asylum applications relative to their population (see also column 1 in Table 1). Country differences in this respect are extremely large. For example, relative to its population, the number of asylum seekers that came to Sweden was 100 times greater than for Portugal. The time period 2006-2017 was chosen to be able to present data for all countries, but results are similar if we were to look at a wider time window, such as 1985 to 2017 (Sanandaji 2018a, 2018b). 
Figure 1 Asylum applications 2006-2017 per thousand inhabitants.

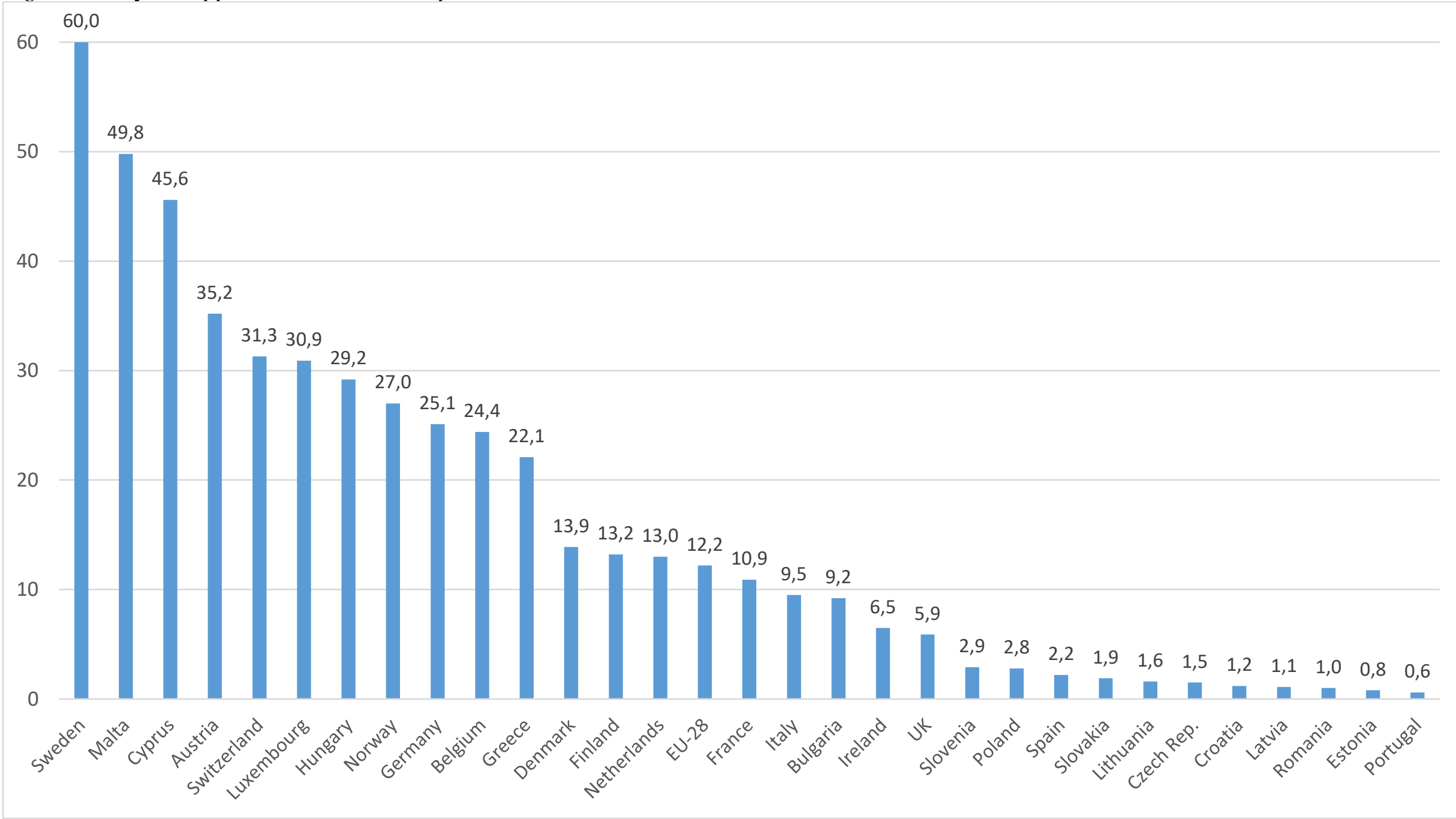

Source: Eurostat. 
The countries that receive the largest number of refugees per capita tend to be either wealthy welfare states such as Sweden and Austria, or small countries in the Mediterranean such as Malta and Cyprus. In the latter case, the large number of asylum seekers is readily explained by the proximity to common transit routes. The countries that receive the lowest number of refugees per capita are either Eastern or Southern European countries. In fact, all Eastern European countries are below the EU average, including relatively wealthy countries such as Estonia and Slovenia. There is also considerable variation among the wealthy Western European countries.

The low figures for Southern Europe are interesting as Southern European Mediterranean countries, such as Portugal and Spain in terms of geographical proximity, are more easily accessed by asylum seekers than Scandinavia or Germany. Similarly, Eastern Europe is also more accessible than Northern Europe. One important explanation is economic circumstances as Northern European countries not only have higher average income but offer refugees far more benefits compared to countries such as Portugal and Croatia.

The United Kingdom is among the Western European countries that receive few refugees, and it did not experience a large inflow during the 2015 crisis either. Nevertheless, the fact that migration policy contributed to the Brexit decision may indicate that dissatisfaction with EU migration from Eastern Europe played an important role (Forslid and Nyberg 2019).

Even excluding Eastern Europe, the variation in refugee flows is extremely large - far larger than one would expect based on differences in economic characteristics. GDP per capita is roughly three times higher in the richest Western European country compared to the poorest, while the top countries in terms of refugee intake per capita, Malta and Sweden, have acceptance rates that are more than 250 times higher than the country that has the lowest acceptance rate, Croatia (column 2 in Table 1). The differences are also huge among the largest European countries: in relation to its population, Germany has granted asylum to four times as many refugees as France and Italy, five times more than the United Kingdom, and 35 times more than Spain. Given these stark differences, it is not surprising that the EU has found it nearly impossible to agree on a common asylum policy by 2019 .

There is also variation over time. For instance, Denmark used to take many refugees but the country has tightened its policy and significantly reduced its refugee intake during the 2010s. 
Some of the countries that used to be the most generous, such as Austria and Denmark, are in 2019 among those countries that have shifted the most towards a restrictive asylum policy. However, few countries have shifted from restrictive to more generous polices. The most notable exception is Germany, which increased its share of granted asylums from around 15 percent of the total EU intake in 2007 to 61 percent in 2017, but since then Germany has also instituted a more restrictive policy. On the other hand, Spain has moved towards a more generous asylum policy following a change in government in 2018. This illustrates the importance of internal political sentiments within member states for migration policy.

For most countries the ranking of countries is similar for the number of applications and the number of granted applications relative to population. There are a few exceptions, notably Hungary, that received a great number of applications but granted rather few. Malta, Germany, Sweden, the Netherlands, and Norway can be found at one extreme, approving over 50 percent of the submitted asylum applications between 2006 and 2017. By contrast, Hungary at the other extreme approved less than two percent of the applications. It is important to note that this percentage may not exactly equal the share of applicants being granted asylum, since there is a lag between applying and being granted asylum, and since some individuals appeal a negative decision. Still, over long periods the ratio between the number of granted asylums to the number of applications gives a good approximation of the share of approved asylum applications. The cross-country differences in this ratio are massive within the EU. Since the countries that have higher ratios also tend to be those that take more asylum seekers, the gap between EU countries becomes even larger when comparing granted asylum.

Table 1 shows that wealthier countries and those with a larger public sector tend to have a more generous asylum policy, but also that the variation in asylum policy is far greater than what can be accounted for by per capita GDP or the size of government. Furthermore, the table shows that there is a large employment gap in most European countries between refugees and the native-born population. In the labor market statistics, country of birth is recorded more often than the reason for migration. Needless to say, many migrants from outside the EU are not refugees. Some are labor migrants from countries such as China, India, and former Soviet republics. 
Table 1 Variations within Europe in asylum seeking, per capita income and employment gaps of non-EU migrants and refugees.

\begin{tabular}{|c|c|c|c|c|c|c|c|}
\hline & $\begin{array}{l}\text { Asylum } \\
\text { appl.* }\end{array}$ & $\begin{array}{l}\text { Granted } \\
\text { asylum } \\
\text { appl.\# }\end{array}$ & $\begin{array}{l}\text { Share of } \\
\text { granted } \\
\text { appl. \% }\end{array}$ & $\begin{array}{c}\text { GDP per } \\
\text { capita }\end{array}$ & $\begin{array}{c}\text { Gov't } \\
\text { spending, } \\
\% \text { of GDP }\end{array}$ & $\begin{array}{c}\text { Employment } \\
\text { gap, non-EU-28 } \\
(2017) \dagger\end{array}$ & $\begin{array}{c}\text { Employment } \\
\text { gap, refugees } \\
(2014) \dagger\end{array}$ \\
\hline Sweden & 60.0 & 30.3 & 50.5 & 33,600 & 50.6 & 19.3 & 25.2 \\
\hline Malta & 49.8 & 31.1 & 62.5 & 23,000 & 40.8 & 7.6 & N.A. \\
\hline Cyprus & 45.6 & 10.3 & 22.7 & 24,800 & 40.9 & 3.4 & N.A. \\
\hline Austria & 35.2 & 15.6 & 44.3 & 34,400 & 51.1 & 16.9 & 15.4 \\
\hline Switzerland & 31.3 & 14.1 & 44.9 & 43,100 & 30.2 & N.A & 6.5 \\
\hline Luxembourg & 30.9 & 7.5 & 24.1 & 70,100 & 42.0 & 6.6 & N.A. \\
\hline Hungary & 29.2 & 0.5 & 1.8 & 17,600 & 49.1 & 1.6 & N.A. \\
\hline Norway & 27.0 & 14.2 & 52.8 & 46,300 & 45.0 & 15.0 & 21.6 \\
\hline Germany & 25.1 & 13.1 & 52.3 & 32,600 & 44.6 & 17.1 & 20.2 \\
\hline Belgium & 24.4 & 7.9 & 32.4 & 31,800 & 52.9 & 19.0 & 23.8 \\
\hline Greece & 22.1 & 3.1 & 14.0 & 21,200 & 51.9 & 4.0 & N.A. \\
\hline Denmark & 13.9 & 6.7 & 48.4 & 33,900 & 54.1 & 17.9 & N.A. \\
\hline Finland & 13.2 & 4.6 & 34.9 & 30,700 & 53.8 & 18.8 & 27.7 \\
\hline Netherlands & 13.0 & 6.6 & 50.5 & 35,600 & 45.3 & 20.5 & N.A. \\
\hline EU-28 & 12.2 & 4.9 & 40.1 & 26,800 & 47.4 & 10.0 & N.A \\
\hline France & 10.9 & 3.1 & 28.4 & 28,700 & 55.9 & 16.9 & 13.6 \\
\hline Italy & 9.5 & 3.6 & 37.3 & 27,200 & 49.5 & 0.2 & -1.5 \\
\hline Bulgaria & 9.2 & 2.7 & 29.1 & 12,000 & 36.9 & 6.7 & N.A. \\
\hline Ireland & 6.5 & 1.1 & 17.1 & 39,900 & 39.3 & 6.6 & N.A. \\
\hline UK & 5.9 & 2.6 & 43.2 & 29,100 & 43.7 & 8.2 & 25.1 \\
\hline Slovenia & 2.9 & 0.3 & 9.8 & 22,600 & 47.7 & 5.4 & -4.6 \\
\hline Poland & 2.8 & 0.4 & 14.7 & 16,900 & 43.2 & -2.1 & N.A \\
\hline Spain & 2.2 & 0.4 & 17.4 & 25,500 & 43.4 & 4.4 & 20.5 \\
\hline Slovakia & 1.9 & 0.3 & 13.7 & 19,800 & 40.8 & 0.3 & N.A. \\
\hline Lithuania & 1.6 & 0.3 & 21.4 & 18,200 & 37.2 & 6.1 & N.A. \\
\hline Czech Rep. & 1.5 & 0.4 & 26.0 & 22,700 & 41.9 & -0.9 & N.A. \\
\hline Croatia & 1.2 & 0.1 & 10.4 & 16,200 & 47.0 & 6.6 & 8.5 \\
\hline Latvia & 1.1 & 0.3 & 26.7 & 16,000 & 38.7 & 8.6 & N.A. \\
\hline Romania & 1.0 & 0.3 & 34.8 & 14,100 & 36.7 & -7.0 & N.A. \\
\hline Estonia & 0.8 & 0.3 & 35.2 & 19,200 & 39.1 & 8.3 & N.A. \\
\hline Portugal & 0.6 & 0.2 & 25.8 & 21,100 & 48.0 & -1.5 & 14.6 \\
\hline
\end{tabular}

Note: The countries were sorted in descending order based on asylum applications per thousand inhabitants (column 1). The table includes all $28 \mathrm{EU}$ member states in 2018 plus Norway and Switzerland regarding the inflow of asylum seekers and the granted share relative to population in 2006-2017, average PPP-adjusted GDP per capita, and government spending as a share of GDP are calculated for the period 2006-2017. The employment gap among between refugees as well as non-European immigrants relative to the native population is for 20-64-year-olds. The native population is defined as all persons where both parents were natively born.

*Asylum applications per thousand inhabitants, 2006-2017. \#Granted asylums per thousand inhabitants, 20062017. $\$$ Measured in PPP-adjusted USD. $\dagger$ In percentage points and latest available year.

Source: Eurostat statistical database.

It is possible to report the employment gap between the native-born population and migrants from outside the EU for all countries in 2017. However, the employment gap for refugees can 
only be presented for some countries (with a lag of some years). Figure 2 presents this gap for Western European countries. Again, we can see that non-EU immigrants are less likely to be employed than the native-born population in all included countries, with the exception of Portugal. The reasons for this state of affairs are complex but can partly be explained migrants' background and skills. While the differences are smaller once one control for education, country of origin and other factors, the EU is far from homogenous when it comes to the labor market performance of migrants (Sanandaji 2017).

The large and persistent differences in asylum policy amongst countries at fairly similar levels of economic development likely reflect strong underlying differences in culture, ideology, politics, and institutions. ${ }^{7}$ Attempts by countries with more generous refugee policies, such as Sweden and Germany, to convince countries that take fewer refugees to increase their intake have thus far failed and caused tensions.

\footnotetext{
${ }^{7}$ For studies trying to explain cross-country differences in migration policies, see Chin and Cortes (2015), Hatton (2016), Keogh (2013), and Toshkov (2014).
} 
Figure 2 Gap in employment rate between native born and non-EU-28 migrants, 2017 (percentage points).

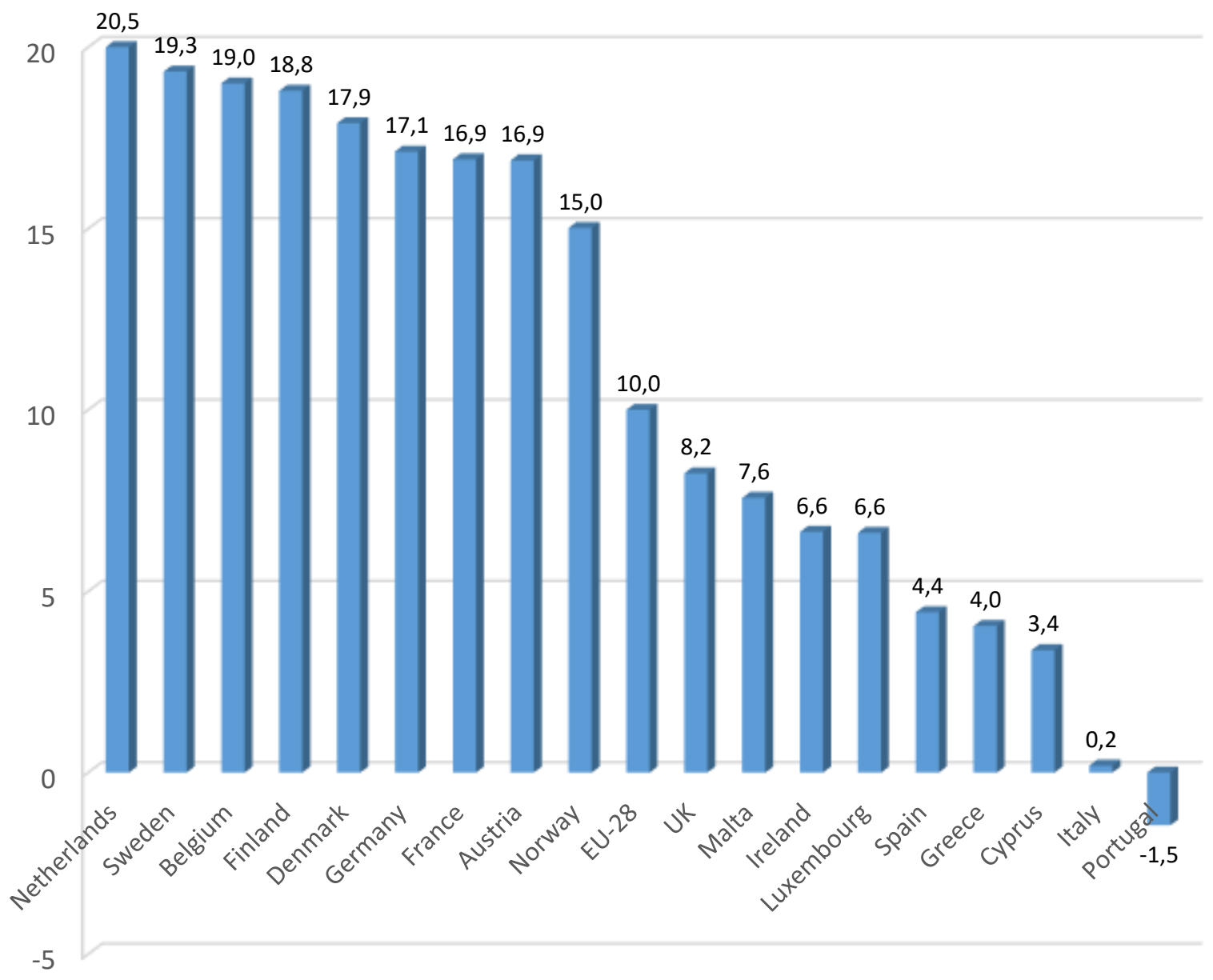

Note: The native-born population consists of all persons where both parents were born in the country.

\section{The Tension between the National and the Federal Level}

Our analysis so far shows that the policies, migration flows, and how well refugees are integrated into the labor market differ immensely across member countries, and there is little public support for a common European asylum policy. Unlike many other policy areas, policies related to refugee migration were never successfully harmonized. The EU countries are simply too far apart in several key respects—such as per capita income, employment opportunities, size and effectiveness of government, political history, and culture - for a meaningful convergence. This has caused tensions as there were attempts to push countries to adopt similar policies, which has undermined support for the European Union as a whole in several countries.

A salient example of the rising political tension within the EU is reflected in the June 2018 meeting in Budapest between the Austrian Chancellor Sebastian Kurz and "the Visegrád four" (Poland, the Czech Republic, Slovakia, and Hungary). The leaders of these five countries 
expressed their dissatisfaction with the dismissal of national identities, rapid centralization in the EU, and imposition of what they deem to be unreasonable immigration quotas (cf. Stegmann McCallion 2019).

On December 4, 2018, the European Commission in a press release called on member states and the EU Parliament prior to the December European Council to "consolidate the significant progress made by adopting the outstanding reform proposals". ${ }^{8}$ Three regulatory and practical issues are emphasized in the report: (i) cooperation between partners, (ii) stronger border management, and (iii) the management of internal migration within the EU. In his statement Vice President Frans Timmerman emphasizes the need for "switching from reactive ad hoc responses to completing the reforms for a sustainable future proof migration and asylum system", acknowledging the ad hoc nature of the asylum process throughout the crisis. In the statement the importance of protecting external borders is repeatedly emphasized, implicitly recognizing the failure in border security during the peak of the crisis. Interestingly, this is one of the few times where the focus is also on improving cooperation with external partners to increase return and readmission.

Moreover, there are two other important issues raised in the press release. First, the need to address the root causes of asylum immigration and the innovative funding instruments that are put in place to manage to do so (e.g., the EU Trust Fund for Africa). Second, the need to expand the existing partnerships built between the EU and the countries in distress. In particular, the return and readmission practices are explicitly mentioned in the press release including the new arrangements that have been instituted since 2016 with countries such as Afghanistan, Guinea, Bangladesh, and Ethiopia. ${ }^{9}$

The European Union's refugee crises challenge relates to the academic debate on the durability of EU federalism. Kelemen (2007, p. 54) argues that federalism is inherently unstable, and that federations may fail either through implosion or explosion. Implosion refers to overcentralization of power at the federal level, which has been at the core of the Eurosceptic debate. Explosion refers to the thinning out of cooperation at the federal level, where members start pursuing their own objectives in opposition to the federal level, which in the worst-case scenario

\footnotetext{
${ }^{8}$ See European Commission (2018c).

${ }^{9}$ See European Commission (2018c). A complete list of readmission agreements and related return-migration practices can be found at the Migration and Home Affairs site of the European Commission (2019c).
} 
can result in gradual disintegration and the eventual demise of the federal system. Even if there were only a few countries that opted out of the system, or if the increased frictions only result in further polarization within the system, that would still indicate that a common EU asylum policy may be detrimental. Hence, every decision at the federal level aiming at furthering the harmonization and decreasing the variation in refugee policies across member states should be thoroughly evaluated prior to implementation. Failing to do so, runs the risk of taking illconceived policy decisions that would lead to further discontent with the EU, and increases the likelihood that the union disintegrates.

\section{Striking a Balance between Asylum Policy at the National and EU Levels}

If one accepts our premise that Europe currently does not have a common asylum policy, more than on paper, it is also worth asking whether the EU in the future should strive for such a policy and federalism in the refugee area. If a common asylum policy is economically and politically rational, the case could be made that the EU and national governments should push harder to make the political rhetoric of a common asylum policy a reality. On the other hand, if attempts to force federalism are not viewed as desirable by a large share of EU citizens, it could backfire and undermine the confidence in the EU cooperation. This type of resistance is likely if there is great variation in EU refugee inflows that reflect underlying economic, cultural, and political factors.

The European Commission has attempted to move towards a more common asylum policy, but the more far-reaching proposals have met with strong political resistance in several member countries. This resistance against a common EU asylum policy is sometimes interpreted as a sign of parochialism and national selfishness, but this stance may just as well reflect a rational assessment. The fact that the refugee issue has given rise to such tension and conflicts between member states strongly suggests that the EU may not be a region for which it is optimal to impose a common asylum policy. The opposition to such an idea thus has a fundamental basis that needs to be weighed in when the European Commission and/or the European Parliament considers various alternatives. Failing to do so, the entire EU project may be jeopardized. Therefore, refugee policies should for the most part be decided upon at the national level. This needs to be done in cooperation with the regional and local levels where the integration measures in the form of education, job matching, provision of housing, health, and so forth are implemented. 
The fact that the EU has succeeded in achieving free movement of labor within the Union does not suggest that it should impose a common asylum policy for the movement from external countries on all its members. The 2015 refugee crisis showed that nation states are capable of regulating asylum policy, whereas the EU was incapable of doing so. However, there may well be an important role for the EU. One difference between a refugee union and a currency union is that asylum policy is far more multi-layered, both vertically and horizontally. It is fully possible for member states to retain elements of asylum policy at the national level, while coordinating on other elements at the federal level. Examples of the latter include refugee aid to countries afflicted by war and natural disasters, treaties with non-member countries for readmission and resettlement, rescue missions in the Mediterranean as well as external border control. Although such objectives have already been clearly stated by the European Commission, ${ }^{10}$ there are still considerable disagreements around them in the public debate of the respective member states. Therefore, it is important that the objectives of the Union regarding a common asylum policy should be better communicated to its member states.

The central policy tools and the agencies that decide on and implement the relevant measures, such as agencies in charge of border controls and assessment of asylum applications, should remain at the national level. This guarantees that their actions are aligned with the interest and political preferences of citizens to regulate migration. The nation state is the unit within which migration and integration policy is conducted and remains the most optimal unit also for regulating inflows, the asylum process, and upholding border controls. Moving forward, refugee migration policy should learn from this experience and acknowledge the important role still played by the nation state.

\footnotetext{
${ }^{10}$ See, e.g. European Commission (2019d).
} 


\section{References}

Andersson, F. N. G. (2019). The euro and the nation state that never disappeared. In A. Bakardjieva Engelbrekt, A. Michalski, \& L. Oxelheim (Eds.), The European Union and the return of the nation state. Cham, $\mathrm{CH}$ : Palgrave Macmillan.

Cherubini, F. (2014). Asylum law in the European Union. New York: Routledge.

Chin, A., \& Cortes, K. E. (2015). The refugee/asylum seeker. In B. R. Chiswick \& P. W. Miller, (Eds.), Handbook of the economics of international migration, vol. 1 (pp. 585658). Amsterdam: North-Holland.

Dilli, S., Elert, N., \& Herrmann, A. M. (2018). Varieties of entrepreneurship: Exploring the institutional foundations of different entrepreneurship types through 'varieties-ofcapitalism' arguments. Small Business Economics 51(2), 293-320.

Elert, N., Henrekson, M., \& Stenkula, M. (2017). Institutional reform for innovation and entrepreneurship - An agenda for Europe. Cham, CH: Springer International Publishing.

Elert, N., Henrekson, M., \& Sanders, M. (2019). The entrepreneurial society: A reform agenda for the European Union. Cham, $\mathrm{CH}$ : Springer International Publishing.

Edsbäcker, K. (2011). Turkey's asylum policy in the light of EU accession - the impact of its geographical limitation to the Geneva Convention (Master's thesis, Lund University, Lund, Sweden). Retrieved from http://lup.lub.lu.se/student-papers/record/2063509.

European Commission. (2016). Proposal on standards for the qualification of third-country nationals or stateless persons as beneficiaries of international protection [...] amending Council Directive 2003/109/EC of 25 November 2003 concerning the status of thirdcountry nationals who are long-term residents. COM(2016) 466 final 2016/0223 (COD), Brussels, 13 July 2016.

European Commission. (2018a). Spring 2018 Standard Eurobarometer: One year ahead of the European elections, trust in the Union and optimism about the future is growing. Retrieved September 21, 2018, from http://europa.eu/rapid/press-release_IP-184148 en.htm.

European Commission. (2018b). Who qualifies for international protection. Retrieved September 18, 2018, from https://ec.europa.eu/home-affairs/what-wedo/policies/asylum/refugee-status_en.

European Commission. (2018c). Managing Migration: Commission calls time on asylum reform stalling, Brussels, 4 December 2018 [Press release], from http://europa.eu/rapid/press-release_IP-18-6627_en.htm.

European Commission. (2019a). Temporary reintroduction of border control. Retrieved August 7, 2019, from https://ec.europa.eu/home-affairs/what-we-do/policies/bordersand-visas/schengen/reintroduction-border-control_en.

European Commission. (2019b). Common European Asylum System. Retrieved August 7, 2019, from https://ec.europa.eu/home-affairs/what-we-do/policies/asylum_en.

European Commission. (2019c). Return \& readmission. Retrieved August 8, 2019, from

https://ec.europa.eu/home-affairs/what-we-do/policies/irregular-migration-returnpolicy/return-readmission_en.

European Commission. (2019d). Migration. Retrieved August 8, 2019, from https://ec.europa.eu/commission/priorities/migration_en.

European Parliament and the Council of the EU. (2013). Regulation (EU) No. 604/2013 of the European Parliament and of the Council of 26 June 2013 establishing the criteria and mechanisms for determining the Member State responsible for examining an application for international protection lodged in one of the Member States by a third-country 
national or a stateless person (recast). Official Journal of the European Union, L 180, 29.6.2013, 31-59.

Eurostat. (2018). Glossary: Migration. Statistics Explained. Retrieved August 07, 2019, from http://ec.europa.eu/eurostat/statistics-explained/index.php/Glossary:Migration.

Forslid, R., \& Nyberg, S. (2019). Brexit and the return of the nation state. In A. Bakardjieva Engelbrekt, A. Michalski, \& L. Oxelheim (Eds.), The European Union and the return of the nation state. Cham, $\mathrm{CH}$ : Palgrave Macmillan.

Faggian, A., \& Öner, Ö. (2018). Location decision of refugees in the receiving country: The Swedish case. Mimeo. Cambridge and Stockholm: Department of Land Economy, Cambridge University and the Research Institute of Industrial Economics.

F. v. United Kingdom. (2004). Application no. 17341/03, Council of Europe: European Court of Human Rights, 22 June 2004, from https://www.refworld.org/cases, ECHR,4ee21ffd2.html.

Hatton, T. J. (2016). Refugees, asylum seekers, and policy in OECD countries. American Economic Review 106(5), 441-445.

Hooghe, L., \& Marks, G. (2001). Multi-level governance and European integration. Lanham, MD: Rowman \& Littlefield.

Johansen, M. (2016, June 12). Rekordmange asylbørn viser sig at være voksne. JyllandsPosten. Retrieved September 22, 2018, from https://jyllandsposten.dk/indland/ECE9207333/rekordmange-asylboern-viser-sig-at-vaere-voksne/.

Kelemen, R. D. (2007). Built to last? The durability of EU federalism. In S. Menuier \& K. R. McNamara (Eds.), Making history: European integration and institutional change at fifty, vol. 8 (pp. 51-66). Oxford: Oxford University Press.

Keogh, G. (2013). Modelling asylum migration pull-force factors in the EU-15. Economic and Social Review 44(3), 371-399.

Lenzerini, F. (2009). Asilo e Diritti Umani: l'Evoluzione del Diritto d'Asilo nel Diritto Internazionale, vol. 10. Siena: Giuffrè Editore.

McGhee, D. (2001). Persecution and social group status: Homosexual refugees in the 1990s. Journal of Refugee Studies 14(1), 20-42.

Mundell, R. A. (1961). A theory of optimum currency areas. American Economic Review 51(4), 657-665.

OECD. (2018). Working together for local integration of migrants and refugees. Paris: OECD Publishing.

Sanandaji, T. (2017). Massutmaning - ekonomisk politik mot utanförskap och antisocialt beteende [Mass challenge: Economic policy against social exclusion and antisocial behavior]. Stockholm: Kuhzad Media.

Sanandaji, T. (2018a). Les Suédois et l'Immigration, Fin de l'Homogénéité? [The Swedes and immigration: End of homogeneity?]. Paris: Fondation pour l'innovation politique. Retrieved from http://www.fondapol.org/wp-content/uploads/2018/08/130-SUEDEIMMIGRATION_I_2018-08-27_web-1.pdf.

Sanandaji, T. (2018b). Les Suédois et l'Immigration, Fin du Consensus? [The Swedes and immigration: End of consensus?]. Paris: Fondation pour l'Innovation Politique. Retrieved from http://www.fondapol.org/wp-content/uploads/2018/08/130-SUEDEIMMIGRATION_II_2018-08-27_web.pdf.

Stegmann McCallion, M. (2019). Europeanisation and the longevity of the nation state: Survival by transformation? In A. Bakardjieva Engelbrekt, A. Michalski, \& L. Oxelheim (Eds.), The European Union and the return of the nation state. Cham, $\mathrm{CH}$ : Palgrave Macmillan. 
Stokes, B., Wike, R., \& Manevich, D. (2017). Post-Brexit, Europeans more favorable toward EU. Pew Research Center.

SVT (2018). SVT:s Vallokalsundersökning: Riksdagsvalet 2018 [SVT's election survey: The Swedish parliamary election 2018]. Retrieved August 7, 2019, from https://www.svt.se/omoss/media/filer_public/5c/17/5c17fc91-31c4-4e0a-a17fb42318edf4a4/valuresultat_riksdagsval_pk_2018_vagda_0912.pdf.

Swedish National Forensic Medicine Agency (2018). Statistik - medicinska åldersbedömningar. Retrieved September 20, 2018, from https://www.rmv.se/verksamheter/medicinskaaldersbedomningar/metoder/manadsstatistik-medicinska-aldersbedomningar/.

Swedish Migration Agency (2018). Verksamhets- och utgiftsprognos 2018-07-29. Dnr. 1.1.32018-929. Norrköping: Migrationsverket.

Toshkov, D. D.oychinov (2014). The Dynamic Relationship between Asylum Applications and Recognition Rates in Europe (1987-2010). European Union Politics 15(2), 192214.

UNHCR. (2002). Protecting refugees: questions and answers. Retrieved September 1, 2018, from http://www.unhcr.org/afr/publications/brochures/3b779dfe2/protecting-refugeesquestions-answers.html.

UNHCR. (2019). Operation portal refugee situations. Retrieved August 7, 2019, from https://data2.unhcr.org/en/situations/mediterranean.

Wennström, J., \& Öner, Ö. (2018). Political hedgehogs: The geographical sorting of refugees in Sweden. IFN Working Paper, no. 1266.

Wessels, J. (2011). Sexual orientation in refugee status determination. Refugee Studies Centre Working Paper, no.73. Oxford: Oxford Department of International Development, University of Oxford. 